\title{
NITROGEN FRACTIONS IN THE MICROBIAL BIOMASS IN SOILS OF SOUTHERN BRAZIL ${ }^{(1)}$
}

\author{
F. A.O. CAMARGO(2), C. GIANELLO(2) $\&$ C. VIDOR ${ }^{(2)}$
}

\begin{abstract}
SUMMARY
The reaction of nitrogen compounds with ninhydrin can be used as an indicator of cytoplasmic materials released from microbial cells killed by fumigation. Total-N, ninhydrin-reactive-N (NR-N), ammonium-N (A-N), and $\alpha$-amino-N in the microbial biomass of soils from the State of R io Grande do Sul, B razil, were determined, in 1996, in $0.5 \mathrm{~mol} \mathrm{~L}^{-1} \mathrm{~K}_{2} \mathrm{SO}_{4}$ extracts of fumigated and non-fumigated soils. Total-N varied from 20.3 to $104.4 \mathrm{mg} \mathrm{kg}^{-1}$ and the ninhydrinreactive-N corresponded, in average, to $27 \%$ of this. The ninhydrin-reactive-N was made up of $67 \%$ ammonium- $\mathrm{N}$ and $33 \%$ aminoacids with the amino group at the $\alpha$-carbon position. It was concluded that colorimetric analysis of NR-N and A-N may be used as a direct measure of microbial $\mathbf{N}$ in soil. This simple and rapid procedure is adequate for routine analyses.
\end{abstract}

Index terms: Biomass-N, biomass ninhydrin-reactive-N, biomass ammonium-N, biomass $\alpha$-amino-N

\section{RESUMO: FRAÇÕES DO NITROGÊNIO NA MICROBIOTA DE SOLOS DO SUL DO BRASIL}

A reação de compostos nitrogenados com a ninhidrina pode ser utilizada como parâmetro indicador dos produtos citoplásmi cos oriundos da lise de células microbianas mortas pel a fumigação. Com basenessa assertiva, realizou-seo presentetrabal ho, em 1996, com o objetivo de avaliar as concentrações de N-total, N-reati vo com ninhidrina (NR-N), $\mathrm{N}$-amônio(A-N) eN-a-ami no presentes na biomassa mi crobiana desolos do Rio Grandedo Sul.A partir da extração com $\mathrm{K}_{2} \mathrm{SO}_{4} 0,5$ mol L-1 deamostras provenientes desol os fumigados enão fumigados, determi naram-seas frações nitrogenadas presentes na biomassa. Constatousequea quantidade do $\mathrm{N}$-total presentena biomassa variou de20,3 a 104,4 $\mathrm{mg} \mathrm{kg}^{1}$ desolo, sendo a fração mi crobiana reativa com a ni nhidrina correspondentea $27 \%$ desses valores, em média. Dois terços dessa fração eram constituídos de nitrogênio na forma de amônio

(1) Received for publication in J anuary of 1997 and aproved in October of 1998.

(2) Professor do Departamento de Solos, Faculdade de Agronomia, Universidade Federal do Rio Grande do Sul. Caixa Postal 776, CEP 90001-970 Porto Alegre (RS). E-mail: Iabsolos@datacontrol.com.br. 
mi crobiano eum terço na forma de aminoáci dos contendo o radical ami no no carbono $\alpha$. É possível utilizar a análise colorimétrica do NR-N e do A-N para a quantificação do $\mathrm{N}$-microbiano do sol o. Tais procedimentos são rápidos, si mples e apl icáveis em análises de rotina.

Termos del ndexação: biomassa microbiana do N, do N-reativo com ninhidrina, do N-amônio e do N- $\alpha$-amino.

\section{INTRODUCTION}

Enzymatic transformations are carried out in soil by microbial biomass to provide nutrients and energy required for synthesis of cell materials. During such transformations, fresh organic materials are stabilized as humus in soil while active microorganisms store $C$ and other nutrients in their protoplasm for support of cell growth (Anderson \& Domsch, 1980). Nutrient storage indicates the level of immobilization which can be achieved and may be used as an indicator of soil potential for mineralization and availability of nutrients to crops.

Classical techniques of microscopy for determination of microbial biomass are timeconsuming and require well-trained staff. Simpler methods have been devel oped using direct extraction of microbial cell constituents mobil ized by fumigation with chloroform (Vance et al., 1987; Amato \& Ladd, 1988). These methods are not affected by the limitations already reported for fumigationincubation including immobilization or denitrification during incubation and interference by labile carbon and nitrogen of non-microbial origin. Thefumigationextraction methods offer the advantage of shorter incubation periods and allow the determination of the nutrient composition of microbial protoplasm from a single extraction (Vance et al., 1987).
Because soil microbial biomass ind udes a notable amount of substances which can be used as a plant nutrient source, their absorption can beinterpreted as soil fertility as the plant responds to their availability, mainly to the microbial nitrogen compounds (Duxbury et al., 1989). Among nutrients, mineralized $\mathrm{N}$ has been correlated with microbial $\mathrm{C}$ and $\mathrm{N}$ in a wide range of soils where considerable increases of inorganic nitrogen were attained after killing microbial cells by air-drying the soil.

This research was carried out to evaluate the concentrations of microbial biomass $\mathrm{N}$ in soils of the state of Rio Grande do Sul in Southern Brazil, and to identify parameters that might form the basis for the development of a rapid and efficient assay for microbial $\mathrm{N}$ determination.

\section{MATERIAL AND METHODS}

Surface soil samples $(0-20 \mathrm{~cm})$ of ten soils showing a wide range in $\mathrm{pH}$ and organic matter (O.M.), nitrogen, and clay content (Tedesco et al., 1995) were taken from representative profile sites (Table 1). The samples were placed in $30 \mathrm{~L}$ buckets and maintained in an open area with native vegetation for over four years. This procedure was

Table 1. Classification and some characteristics of Rio Grande do Sul soils used in the study

\begin{tabular}{|c|c|c|c|c|c|c|c|}
\hline $\begin{array}{l}\text { Soil number and } \\
\text { location }\end{array}$ & $\begin{array}{c}\text { Soil } \\
\text { classification }\end{array}$ & Soil taxonomy & $\begin{array}{l}\text { Area in the } \\
\text { state }\end{array}$ & Clay & $\begin{array}{c}\text { pH } \\
\left(\mathbf{H}_{2} \mathbf{O}\right)\end{array}$ & Total-N & O.M..$^{(1)}$ \\
\hline & & & $\%$ & $\mathrm{~g} \mathrm{dm}^{-3}$ & & \multicolumn{2}{|c|}{$-\mathrm{g} \mathrm{kg}^{-1}-$} \\
\hline 1. Santo Ângelo & Dusky-Red L atosol & Haplortox & 7.26 & 550 & 6.4 & 1.42 & 17 \\
\hline 2. Passo Fundo & Red Yellow Latosol & Haplortox & 2.80 & 240 & 4.7 & 1.00 & 19 \\
\hline 3. Bom Retiro & Red Yellow Podzolic & Paleodult & 1.00 & 180 & 4.0 & 0.90 & 23 \\
\hline 4. Cruz Alta & Dark-Red Latosol & Haplortox & 2.95 & 240 & 5.4 & 1.61 & 29 \\
\hline 5. Santa Maria & Dark-Red Latosol & Haplortox & 1.87 & 360 & 5.0 & 2.03 & 33 \\
\hline 6. J úlio de Castilhos & Red Yellow Podzolic & Paleohumult & 0.73 & 130 & 5.4 & 1.81 & 33 \\
\hline 7. Bagé & Red Yellow Podzolic & Paleodult & 0.68 & 330 & 4.1 & 1.90 & 36 \\
\hline 8. Erechim & Dusky-Red Latosol & Haplortox & 4.75 & 470 & 4.8 & 2.51 & 47 \\
\hline 9. Estação & Terra Roxa Estruturada & Paleodult & 1.22 & 400 & 4.4 & 3.62 & 51 \\
\hline 10. Bom J esus & Humic Cambisol & Haplumbrept & 1.42 & 320 & 4.6 & 3.10 & 56 \\
\hline
\end{tabular}

(1) Organic matter. 
used to minimize sampling and handling effects of transport and collection of soil samples which were also air-dried, sieved $(2 \mathrm{~mm})$ and stored at $4^{\circ} \mathrm{C}$ for later analysis. Triplicate soil subsamples $(20 \mathrm{~g})$ were subjected to fumigation-extraction according to the procedures described by Vance et al. (1987). After chlor oform removal, treated and untreated soil samples were extracted with $0.5 \mathrm{~mol} \mathrm{~L}^{-1} \mathrm{~K}_{2} \mathrm{SO}_{4}$ (1:5 soil:extractant). The extracts were filtered for analysis of total-N (micro kjeldahl), ninhydrinreactive-N (NR-N), ammonium- $\mathrm{N}\left(\mathrm{NH}_{4}-\mathrm{N}\right.$ by steam distillation with $\mathrm{MgO}$ ), and the $\alpha$-amino- $\mathrm{N}$ as measured by the difference between ammonium-N and NR-N (Carter, 1991). The difference between fumigated and non-fumigated extracts $\left(E_{n}=\right.$ nitrogen flush) was divided by a constant $K_{\text {en }}=0.54$ (Brookes et al., 1985) to give the microbial biomass$\mathrm{N}$. NR-N was determined by adding a recently prepared ninhydrin reagent (Badalucco et al., 1992) to soil extracts at a 1:5 ratio (extract:ninhydrin) in water bath at $80^{\circ} \mathrm{C}$ for $20 \mathrm{~min}$. Colorimetric determinations at $570 \mathrm{~nm}$ were made after cooling the samples and the NR-N concentrations estimated in a standard curve of glucosamine- $\mathrm{HCl}$.

Biomass ninhydrin-N (NR-N) was calculated from NR-N $=[(N R-N$ in extracts of fumigated soil) minus (NR-N in extracts of non-fumigated soil)]. Biomass ammonium-N was calculated similarly, and biomass $\alpha$-amino- $N$ by difference. Thus, biomass $\alpha$-amino- $\mathrm{N}=[(\mathrm{NR}-\mathrm{N}$ minus ammonium- $\mathrm{N}$ in extracts of fumigated soil) - (NR-N minus ammonium-N in extracts of non-fumigated soil)] (J oergensen \& Brookes, 1990).

\section{RESULTS AND DISCUSSION}

Total- $\mathrm{N}$ in the microbial biomass varied between 20.3 and $104.4 \mathrm{mg} \mathrm{kg}^{-1}$, the highest concentrations being found in soils with highest total $\mathrm{N}$ and organic matter contents (Table 2 ). I n general, these results agree with those obtained by Brookes et al. (1985) in $18 \mathrm{English}$ soils. These authors found that the amount of $\mathrm{N}$ released by fumigation-extraction was highly correlated with organic N, probably representing microbial cytoplasm $\mathrm{N}$.

Values of NR-N varied between 5.7 and $27.2 \mathrm{mg} \mathrm{kg}^{-1}$ (Table 2), which are, in average, $22 \%$ lower than those obtained by J oergensen \& Brookes (1990) and slightly lower than those shown for Italian soils by Badalucco et al. (1992). These differences in biomass content are directly related to the primary factors affecting microbial ecology. Among these factors, temperate climatic conditions (J oergensen \& Brookes, 1990) tend to increase the easily biodegradableorganic material, which, in turn, causes an increase in the microbial population, if conditions are adequate for microbial growth. As expected in these conditions, microbial biomass is higher than in those found in Australian soils by Sparling et al. (1993). Subtropical, desert and arid conditions prevail in most of the Australian land mass. This, together with the intense agricultural activity occurring in those areas from which the soil samples were taken, limits the establishment and growth of microbial biomass, especially because of high temperatures and low humidity, associated with a reduced amount of organic material. This situation, although less accentuated, also occurs in the Brazilian soils studied in this work.

Microbial ammonium- $\mathrm{N}$ varied from 4.0 to $18.0 \mathrm{mg} \mathrm{kg}^{-1}$, representing $66 \%$ of the NR-N. $\alpha$-amino-N present at concentrations varying from 1.7 to $9.2 \mathrm{mg} \mathrm{kg}^{-1}$, which were $19 \%$ less, in average, than those found by J oergensen \& Brookes (1990). This difference is also reflected in the total- $\mathrm{N}$ present. These authors found that NR-N values of 12 soils were 15.8 times higher than the $\alpha$-amino-N in the biomass. In the present work, NR-N was 11.3 times higher than the a-amino-N.

Table 2. Total-N, ninhydrin reactive-N, ammonium-N, and $\alpha$-amino-N in soil microbial biomass, determined by extraction with $0.5 \mathrm{~mol} \mathrm{~L}^{-1} \mathrm{~K}_{2} \mathrm{SO}_{4}$

\begin{tabular}{|c|c|c|c|c|}
\hline Soil number & Total-N & Ninhydrin reactive-N & Ammonium-N & $\alpha$-amino-N \\
\hline & \multicolumn{4}{|c|}{$-\mathrm{mg} \mathrm{kg}^{-1}$} \\
\hline 1 & $22.3 \pm 3.8^{(1)}$ & $6.0 \pm 2.9$ & $4.0 \pm 1.4$ & $1.7 \pm 0.5$ \\
\hline 2 & $20.3 \pm 5.0$ & $5.7 \pm 1.4$ & $4.0 \pm 0.9$ & $1.7 \pm 0.2$ \\
\hline 3 & $32.1 \pm 8.9$ & $8.6 \pm 2.8$ & $4.3 \pm 1.3$ & $2.2 \pm 0.8$ \\
\hline 4 & $33.4 \pm 8.6$ & $9.6 \pm 1.9$ & $6.8 \pm 1.3$ & $2.8 \pm 0.7$ \\
\hline 5 & $40.2 \pm 7.9$ & $11.5 \pm 1.7$ & $7.0 \pm 2.7$ & $4.6 \pm 0.7$ \\
\hline 6 & $39.1 \pm 7.1$ & $11.6 \pm 3.9$ & $7.0 \pm 1.9$ & $4.5 \pm 0.9$ \\
\hline 7 & $41.4 \pm 11.3$ & $13.7 \pm 6.1$ & $9.1 \pm 4.0$ & $4.6 \pm 1.9$ \\
\hline 8 & $80.3 \pm 7.9$ & $20.8 \pm 4.5$ & $15.4 \pm 3.4$ & $5.4 \pm 1.6$ \\
\hline 9 & $104.4 \pm 18.4$ & $27.2 \pm 5.7$ & $18.0 \pm 5.5$ & $9.2 \pm 2.6$ \\
\hline 10 & $78.7 \pm 28.4$ & $19.9 \pm 8.0$ & $13.2 \pm 6.0$ & $6.7 \pm 3.3$ \\
\hline
\end{tabular}

(1) \pm Standard deviation. 
There was little variability for the replicates of the fractions evaluated, as estimated by the standard deviation (Table 2), compared with figures obtained by other workers. This was probably because of the limited variability of the characteristics of the soils chosen in this study, and confirms the viability of the method for determining nitrogen compounds in soil biomass. However, the method should be calibrated for total- $\mathrm{N}$ in biomass for routine use. Analysis of simple correlation gave high correlation coefficients between total- $\mathrm{N}$ in biomass determined by sulfuric digestion of the extract and the fractions NR-N ( $\left.R^{2}=0.98\right)$, ammonium-N $\left(R^{2}=0.96\right)$ and $\alpha$-amino-N $\left(\mathrm{R}^{2}=0.88\right)$.

The ratio between NR-N and total- $\mathrm{N}$ in biomass is influenced by environmental conditions and by the different soils studied. This is shown by the values for the MB-N/NR-N ratio found in other studies: 3.1 (Amato \& Ladd, 1988), 4.0 (I nobushi et al., 1991), 5.0 (J oergensen \& Brookes, 1990), 5.1 (Carter, 1991) and 6.5 (Badalucco et al., 1992; Sparling et al., 1993); the value found here (5.4) lies among the higher figures quoted. These differences may be explained by variations in methodology and soil characteristics. Now that the experimental conditions have been standardized, it is possible to point out certain differences previously observed in the results obtained for the various soils. Soil No. 1 (Table 1) was, originally, moderately acid and had low base saturation (data not shown). With the intensification of cultivation and concomitant correction of acidity with lime, the $\mathrm{pH}$ rose to 6.4. Under these new conditions, the microbial activity would have increased, promoting the consumption of the more labile fractions of the soil N. As a result, the microbial population would decline because of substrate limitation. This limitation could be influenced by abiotic factors. This can be seen in soil No. 10 (Table 1), in which low pH, high aluminum level and low average annual temperatures may have restricted microbial growth.

According to the literature, NR-N represents about $18 \%$ of the total- $\mathrm{N}$ in microbial biomass. Solubilization of the microbial cells by $\mathrm{K}_{2} \mathrm{SO}_{4}$ and the subsequent treatment with ninhydrin releases $\mathrm{NH}_{2}$ radicals on the $\alpha-C$, which are not intimately associated with the fraction having more complex $\mathrm{N}$-containing molecules (Carter, 1991). Sulfuric digestion completely hydrolyzes molecules such as the polymers $\mathrm{N}$-acetyl glucosamine and muramic acid (components of fungal and bacterial cell walls), amino sugars (present in structural membranes and fungal mycelia) and certain amino acids which do not react with ninhydrin (arginine, histidine, Iysine and proline) because they have amino groups on other positions rather than the $\alpha-\mathrm{C}$ atom (Camargo et al., 1997a). Although it does not identify these types of nitrogen, NR-N is strongly correlated with total-N in microbial-biomass- $N\left(R^{2}=0.98\right)$.
The high values of microbial ammonium-N (13\% of total-N in microbial biomass) found in this work may be associated to the feedback inhibition by glutamate synthase and glutamine synthetase (GS) that causes amino acid synthesis reduction and accumulation of ammonium by the cell (Nheidhardt et al., 1990). However, this inorganic fraction could include $\mathrm{N}$ from highly soluble amine and amide radicals, released by the extraction technique (Camargo et al., 1997b). Even so, the concentrations of microbial ammonium- $\mathrm{N}$ were highly correlated with total microbial-N $\left(R^{2}=0.96\right)$ suggesting that col orimetric determination of ammonium could also be used as an indicator of microbial nitrogen.

The main advantage of direct extraction is that, apart from microbial biomass, it is possibletoanalyze other components which are immobilized in the microbial protoplasm. Total-N analysis is a form of quantifying the amount of $\mathrm{N}$ in the biomass, with another being the quantification of NR-N; in this study, this fraction represented an average of $27 \%$ of the total-N. It is also possible to use colorimetric analysis of NR-N and microbial ammonium-N as a direct measure of microbial $\mathrm{N}$ in soil. This is a rapid and easy method for routine analysis, compared to sulfuric acid digestion.

\section{LITERATURE CITED}

AMATO, M. \& LADD, J.N. An assay for microbial biomass based on ninhydrin-reactive nitrogen in extracts of fumigated soils. Soil Biol. Biochem., 20:107-114, 1988.

ANDERSON, J.P.E. \& DOMSCH, K.H. Quantities of plant nutrients in the microbial biomass of selected soils. Soil Biol. Biochem., 130:211-216, 1980.

BADALUCCO, L.; GELSOMINO, A.; DELL'ORCO, S. GRECO, S. \& NANNIPIERI, P. Biochemical characterization of soil organic compounds extracted by $0.5 \mathrm{M} \mathrm{K}_{2} \mathrm{SO}_{4}$ before and after chloroform fumigation. Soil Biol. Biochem., 24:569578, 1992.

BROOKES, P.C.; LANDMAN, A.; PRUDEN, G. \& J ENKINSON, D.S. Chloroform fumigation and the rel ease of soil nitrogen: a rapid direct extraction method for measuring microbial biomass nitrogen in soil. Soil Biol. Biochem., 17:837-842, 1985.

CAMARGO, F.A.O.; GIANELLO, C. \& VIDOR, C. Tempo de hidrólise e concentração de ácido para fracionamento do nitrogênio orgânico do solo. Pesq. Agropec. Bras., 32:221227, 1997a.

CAMARGO, F.A.O.; GIANELLO, C. \& VIDOR, C. Comparative study of five hydrolytic methods in the determination of soil organic nitrogen compounds. Comm. Soil Sci. Plant Anal., 28:13030-13090, 1997b. 
CARTER, M.R. Ninhydrin-reactiveN released by the fumigationextraction method as a measure of microbial biomass under field conditions. Soil Biol. Biochem., 23:139-143, 1991.

DUXBURY, J.M.; SMITH, M.S. \& DORAN, J.W. Organic matter as a source and sink of plant nutrients. In: COLEMAN, D.C.; OADES, J.M. \& UEHARA, G., eds. Dynamics of soil organic matter in tropical ecosystems. Honululu, University of Hawaii Press, 1989. p.33-68.

INOBUSHI, K.; BROOKES, P.C. \& J ENKINSON, D.S. Soil microbial biomass $\mathrm{C}, \mathrm{N}$, and ninhydrin- $\mathrm{N}$ in aerobic and anaerobic soils measured by the fumigation-extraction method. Soil Biol. Biochem., 23:737-741, 1991.

J OERGENSEN, R.G. \& BROOKES, P.C. Ninhydrin-reactive nitrogen measurements of microbial biomass in $0.5 \mathrm{M}$ $\mathrm{K}_{2} \mathrm{SO}_{4}$ soil extracts. Soil Biol. Biochem., 22:1023-1027, 1990.
NHEIDHARDT, F.C.; INGRAHAM, J.L. \& SCHAECHTER, M. Biosynthesis and fuelling. In: Physiology of the bacterial cell: a molecular approach. Massachusetts, Sinauer Publishers, 1990. p.133-173.

SPARLING, G.P.; GUPTA, V.V.S.R. \& ZHU, C. Release of ninhydrin-reactive compounds during fumigation of soil to estimate microbial C and N. Soil Biol. Biochem., 25:10831085, 1993.

TEDESCO, M.J .; GIANELLO, C.; BISSANI, C.; BOHNEN, H. \& VOLKWEISS, S.J. Análises de solo, plantas e outros materiais. 2 ed. Porto Alegre, Universidade Federal do Rio Grande do Sul, 1995. 174p. (Boletim Técnico, 5)

VANCE, E.D.; BROOKES, P.C. \& JENKINSON, D.S. An extraction method for measuring soil microbial biomass $C$. Soil Biol. Biochem., 19:697-702, 1987. 